\title{
Farnesol inhibits cell proliferation and induces apoptosis after partial hepatectomy in rats $^{1}$
}

\author{
Farnesol inibe a proliferação celular e induz a apoptose após a hepatectomia parcial em ratos
}

\author{
Carlos Eduardo Andrade Chagas ${ }^{\mathrm{I}}$, Alessandra Vieira ${ }^{\mathrm{II}}$, Thomas Prates Ong ${ }^{\mathrm{III}}$, Fernando Salvador Moreno ${ }^{\mathrm{IV}}$ \\ ${ }^{I}$ RD, MSc, Fellow PhD degree, Faculty of Pharmaceutical Sciences, USP, Sao Paulo, Brazil. \\ ${ }^{\text {II }}$ BS, MSc, Fellow PhD degree, Faculty of Pharmaceutical Sciences, USP, Sao Paulo, Brazil. \\ III Pharm. D, PhD, Assistant Professor, Department of Food and Experimental Nutrition, Phaculty of Pharmaceutical Sciences, USP, Sao Paulo, Brazil. \\ ${ }^{\text {IV }} \mathrm{MD}$, PhD, Full Professor, Department of Food and Experimental Nutrition, Faculty of Pharmaceutical Sciences, USP, Sao Paulo, Brazil.
}

\begin{abstract}
Purpose: To study farnesol (FOH) effects on liver regeneration after 70\% partial hepatectomy (PH) in rats. Methods: Animals received FOH (25 mg/100 g body weight/day) or corn oil (CO, $0.25 \mathrm{~mL} / 100 \mathrm{~g}$ body weight/day, controls). After a 2 week-treatment, all animals were subjected to PH and euthanized at different time points ( 0 h, 0.5 h, 4 h, 8 h, $18 \mathrm{~h}$ and $24 \mathrm{~h})$ after surgery. Hepatic cell proliferation (PCNA positive nuclei) and apoptosis (fluorescence microscopy) were evaluated. Results: Compared to $\mathrm{CO}$ treatment, FOH treatment inhibited $(\mathrm{p}<0.05)$ cell proliferation at $24 \mathrm{~h}$ ( $\mathrm{S}$ phase of the cell cycle) after $\mathrm{PH}$. This was preceded by an induction of apoptosis $0.5 \mathrm{~h}$ $\left(\mathrm{p}<0.05 ; \mathrm{G}_{0} / \mathrm{G}_{1}\right.$ transition phase) after surgery. Conclusion: The results of the present study suggest that apoptosis induction could be associated with the reduced number of cells at the $\mathrm{S}$ phase observed in FOH group. These novel in vivo data reinforce FOH as a promising chemopreventive and therapeutic agent against cancer.
\end{abstract}

Key words: Farnesol. Hepatectomy. Cell Proliferation. Apoptosis. Rats.

\section{RESUMO}

Objetivo: Estudar o efeito do farnesol $(\mathrm{FOH})$ durante a regeneração hepática em ratos submetidos à Hepatectomia Parcial (HP) a 70\%. Métodos: Os animais foram tratados com FOH $(25 \mathrm{mg} / 100 \mathrm{~g}$ de peso corpórel/dia) ou óleo de milho $(\mathrm{OM}, 0,25 \mathrm{~mL} / 100 \mathrm{~g}$ de peso corpóreo/dia, grupo controle). Depois de 2 semanas de tratamento, todos os animais foram submetidos à HP e eutanaziados em diferentes momentos (0h, 30min., 4h, 8h, 18h, 24h.) após o procedimento cirúrgico. Foi avaliada a proliferação celular (imunohistoquímica para PCNA) e a apoptose (microscopia de fluorescência). Resultados: Em comparação aos animais controles, animais tratados com FOH apresentaram menor $(\mathrm{p}<0,05)$ proliferação celular 24h. (fase $\mathrm{S}$ do ciclo celular) após a HP. Tal efeito foi precedido de uma indução de apoptose $30 \mathrm{~min}$. ( $<<0,05$; transição entre as fases $\mathrm{G}_{0} / \mathrm{G}_{1}$ do ciclo celular) após a cirurgia. Conclusão: Os resultados do presente estudo sugerem que a indução da apoptose pode estar associada com o menor número de células na fase $\mathrm{S}$ observadas nos animais tratados com FOH. Essa nova evidência in vivo reforça o farnesol como um promissor agente preventivo e terapêutico contra o câncer.

Descritores: Farnesol. Hepatectomia. Proliferação de Células. Apoptose. Ratos.

${ }^{1}$ Research performed at the Laboratory of Diet, Nutrition and Cancer, Department of Food and Experimental Nutrition, Faculty of Pharmaceutical Sciences, University of Sao Paulo (USP), Brazil.

\section{Introduction}

Cancer is an important global public health problem. The American Cancer Society projected 1,437,180 new cancer cases and 565,650 deaths form cancer in $2008^{1}$. Despite advances in therapy, prognosis for patients with cancer remains poor. Thus chemoprevention is considered a relevant strategy for cancer control $^{2}$.

Diet-derived isoprenoids present inhibitory effect against colon $^{3,4}$, pancreas ${ }^{5,6}$ and liver ${ }^{7,8}$ carcinogenesis. They comprise a class of substances with over 20,000 constituents widely distributed in fruits and vegetables. Farnesol (FOH), a 15 -carbon isoprenoid present in orange peel and lemon-grass oil and strawberries, has been considered a promising cancer chemopreventive $^{8,9}$ and therapeutic agent ${ }^{10}$. Although FOH inhibited cell proliferation and induced apoptosis in vitro, in vivo information is scarce ${ }^{11}$. In rodents, these actions were observed during chemically induced pancreas ${ }^{5,6}$ and $\operatorname{liver}^{8}$ carcinogenesis, but not in models specifically designed for the study of cell proliferation.

The 70\% partial hepatectomy $(\mathrm{PH})$ is considered a classic, highly regulated and orchestrated model for the study of cell proliferation during liver regeneration ${ }^{12}$. After $\mathrm{PH}$, most remaining hepatocytes promptly enter and progress in the cell cycle in a synchronous manner. The first stage (priming), in which hepatocytes undergo transition from resting state $\left(G_{0}\right)$ to one in 
which they become capable to proliferate $\left(G_{1}\right)$, lasts 4-6 h after $\mathrm{PH}^{14}$. Then, these primed hepatocytes enter a progression stage, with DNA synthesis starting around $18 \mathrm{~h}$ and peaking at $24 \mathrm{~h}$ after $\mathrm{PH}^{12-14}$. The objective of the present study was to investigate the effect of $\mathrm{FOH}$ administration in rats submitted to $\mathrm{PH}$, a synchronized and well caracterized model for the study of cell proliferation.

\section{Methods}

\section{Chemicals}

FOH (trans, trans-3, 7, 11-trimethyl-2, 6, 10dodecatrien-1-ol; 96\%) was purchased from Aldrich. 3,3'diaminobenzidine and bovine serum albumin were purchased from Sigma. The commercial diet was purchased from Purina ${ }^{\circledR}$. Corn oil (CO) was Mazola ${ }^{\circledR}$. Polyclonal anti-proliferative cell nuclear antigen (PCNA) rat antibody, secondary biotinylated antibody and streptavidin-biotin-peroxidase complex were purchased from Dako.

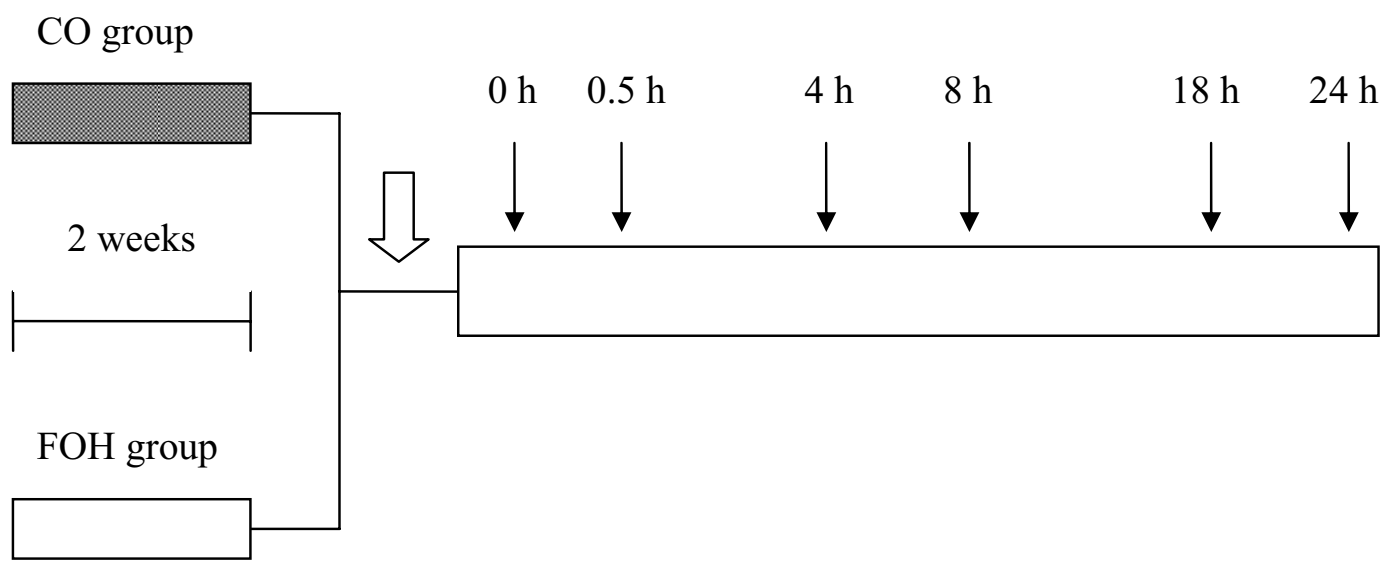

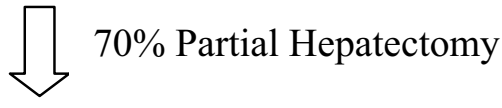

FIGURE 1 - Experimental design
Euthanasia.

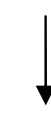

Euthanasia.

\section{Animals and treatment}

Male Wistar rats from the colony of the Faculty of Pharmaceutical Sciences, initially weighing $50 \mathrm{~g}$ maintained in cages with four animals, at constant temperature $\left(22^{\circ} \mathrm{C}\right)$, with $12 \mathrm{~h}$ light-dark cycle and receiving water and commercial diet ad libitum, were used.

Figure 1 illustrates the experimental design. At the end of a 7-day acclimatization period, 102 animals were randomly divided into 2 experimental groups. FOH group received FOH (25 mg/100 $\mathrm{g} \mathrm{bw})$ dissolved in $\mathrm{CO}(0.25 \mathrm{~mL} / 100 \mathrm{~g} \mathrm{bw})$. CO group (control) received only $\mathrm{CO}$. Both treatments were performed by gavage daily for 2 consecutive weeks. Afterwards, all animals were submitted to a $70 \% \mathrm{PH}$ as previously described ${ }^{15}$ and euthanized at $0 \mathrm{~h}, 0.5 \mathrm{~h}$, $4 \mathrm{~h}, 8 \mathrm{~h}, 18 \mathrm{~h}$ and $24 \mathrm{~h}$ after surgery. The last dose of FOH was administrated $2 \mathrm{~h}$ before euthanasia. The study was carried out within the guidelines of the Brazilian College of Animal Experiments (COBEA) and was approved by the Faculty of Pharmaceutical Sciences Ethic Committee for the Care and Use of Laboratory Animals (protocol number 16).
(CO) corn oil, $0,25 \mathrm{~mL} / 100 \mathrm{~g}$ body weight/day

(FOH) farnesol, $25 \mathrm{mg} / 100 \mathrm{~g}$ body weight/day

\section{Hepatic cell proliferation analysis}

To evaluate cell proliferation, representative fragments of each liver lobe were fixed in methacarn solution $(60 \%$ methanol, $30 \%$ chloroform and $10 \%$ glacial acetic acid) for $24 \mathrm{~h}$ and included in paraffin. Histological sections of $5 \mu \mathrm{m}$ were processed in order to detect PCNA-positive hepatocytes as described by Fonseca et al. ${ }^{16}$. Basically, after paraffin removal, endogenous peroxidase was blocked by $20 \%$ hydrogen peroxide in methanol for $0.5 \mathrm{~h}$. Thereafter, the sections were incubated overnight at $4^{\circ} \mathrm{C}$ with primary anti-PCNA rat antibody at a 1:1600 dilution in $1 \%$ bovine serum albumin. Finally, the sections were incubated for $1 \mathrm{~h}$ with secondary biotinylated antibody and thereafter the streptavidinbiotin-peroxidase complex was applied. Peroxidase binding sites were detected by incubation with 3,3'-diaminobenzidine $(0.5 \%)$ and hydrogen peroxide $(0.1 \%)$ dissolved in phosphate buffer saline (PBS), for $2 \mathrm{~min}$ at room temperature. Sections were counterstained with hematoxylin. The entire liver section was 
analyzed using light microscope. Cell proliferation index (CPI) was expressed as the number of PCNA-positive nuclei $/ \mathrm{mm}^{2}$ histological liver section ${ }^{8}$.

\section{Hepatic apoptosis evaluation}

Hepatic apoptotic bodies (AB) were quantified by fluorescence microscopy as previously described ${ }^{8}$ using a Nikon microscope equipped with an epifluorescence unit. This method is based on the strong eosin fluorescence of $\mathrm{AB}$ in hematoxylin and eosin (H\&E) stained liver tissues submitted to blue light (450-490 nm). Identification of AB was confirmed by switching the microscope system from blue to transmitted light and using morphological criteria established by Goldsworth et al. ${ }^{17}$. AB were represented by acidophilic bodies with fragmentation or lack of chromatin accompanied by cytoplasmatic condensation and/or fragmentation ${ }^{17}$. If single cells or clusters of directly neighbouring cell contained multiple $\mathrm{AB}$, these were assumed to be derived from the same apoptotic cell and were counted as only one event. The entire liver section was analyzed. Apoptotic index (AI) was expressed as the number of hepatic $\mathrm{AB} / \mathrm{mm}^{2}$ of histological section ${ }^{8}$.

\section{Statistical analysis}

Sigma Stat 2.0 program was used for statistical analysis. For all analyzed parameters a two-way ANOVA followed by a Tukey test was performed in order to identify any significant differences between $\mathrm{CO}$ and $\mathrm{FOH}$ group in all euthanasia time points. In all cases a level of significance of $p<0.05$ was applied.

\section{Results}

\section{Absolute and relative liver weights}

Absolute and relative liver weights of rats treated with FOH or $\mathrm{CO}$ and submitted to $70 \% \mathrm{PH}$ are shown in Table 1. No statistically significant $(\mathrm{p}>0.05)$ differences were observed between experimental groups in all euthanasia time-points regarding absolute and relative liver weights. These results suggest that FOH did not present toxicity. FOH dosage was based on our previous study in which it did not present any apparent toxicity when administered during 8 consecutive weeks to rats submitted to a hepatocarcinogenesis model ${ }^{8}$.

TABLE 1 - Absolute and relative liver weight of rats treated for two consecutive weeks with $\mathrm{CO}$ or FOH and submitted to PH

\begin{tabular}{lcccccc}
\hline \multicolumn{7}{c}{ Absolute liver weight (g) } \\
\hline Euthanasia & & & & & \\
time points & $0 \mathrm{~h}(\mathrm{n}=9)$ & $0.5 \mathrm{~h}(\mathrm{n}=8)$ & $4 \mathrm{~h}(\mathrm{n}=9)$ & $8 \mathrm{~h}(\mathrm{n}=8)$ & $18 \mathrm{~h}(\mathrm{n}=8)$ & $24 \mathrm{~h}(\mathrm{n}=9)$ \\
CO & $3,66 \pm 0,2$ & $3,45 \pm 0,1$ & $3,34 \pm 0,2$ & $3,75 \pm 0,1$ & $4,11 \pm 0,1$ & $4,29 \pm 0,2$ \\
FOH & $3,72 \pm 0,2$ & $3,42 \pm 0,2$ & $3,64 \pm 0,1$ & $3,94 \pm 0,1$ & $4,38 \pm 0,2$ & $4,38 \pm 0,2$
\end{tabular}

Relative liver weight (g/100g of body weight)

\begin{tabular}{lcccccc}
\hline Euthanasia & & & & & \\
time points & $0 \mathrm{~h}(\mathrm{n}=9)$ & $0.5 \mathrm{~h}(\mathrm{n}=8)$ & $4 \mathrm{~h}(\mathrm{n}=9)$ & $8 \mathrm{~h}(\mathrm{n}=8)$ & $18 \mathrm{~h}(\mathrm{n}=8)$ & $24 \mathrm{~h}(\mathrm{n}=9)$ \\
CO & $1,19 \pm 0,1$ & $1,15 \pm 0,1$ & $1,1 \pm 0,1$ & $1,22 \pm 0,0$ & $1,41 \pm 0,1$ & $1,45 \pm 0,1$ \\
FOH & $1,18 \pm 0,1$ & $1,15 \pm 0,1$ & $1,19 \pm 0,0$ & $1,32 \pm 0,1$ & $1,46 \pm 0,0$ & $1,47 \pm 0,1$
\end{tabular}

* Data are means \pm SEM.

FOH effects on hepatic cell proliferation and apoptosis

Figure 2 shows CPI of animals of $\mathrm{FOH}$ and $\mathrm{CO}$ groups. Until $18 \mathrm{~h}$ after surgery no statistically significant differences $(\mathrm{p}>0.05)$ were observed regarding $\mathrm{FOH}$ and $\mathrm{CO}$ groups CPI.
In $\mathrm{CO}$ group, the highest CPI was observed $24 \mathrm{~h}$ after surgery. Compared to $\mathrm{CO}$ group, $\mathrm{FOH}$ group presented smaller $(\mathrm{p}<0.05)$ CPI $24 \mathrm{~h}$ after PH. 


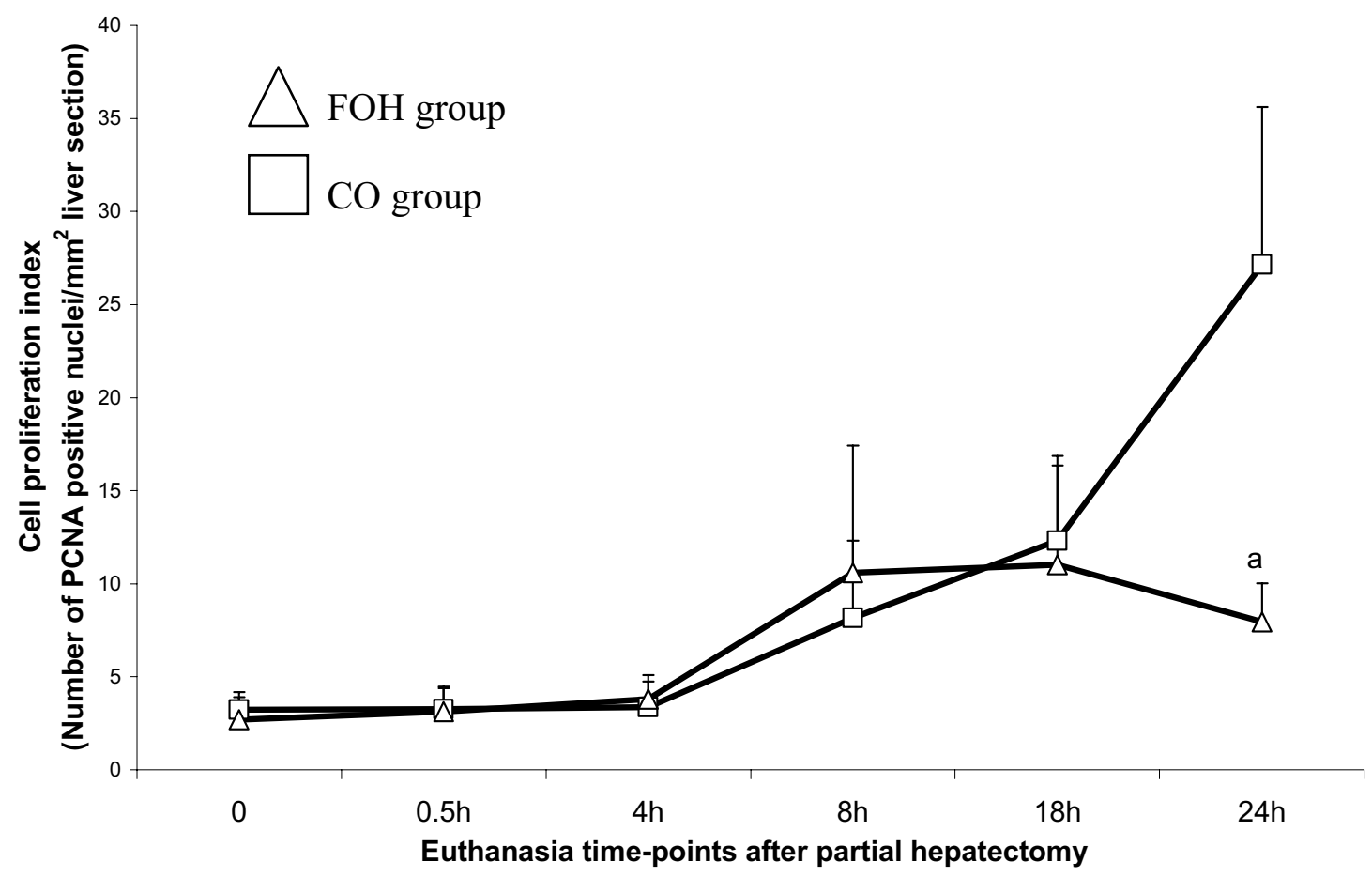

FIGURE 2 - Hepatic cell proliferation index (CPI) of rats treated for 2 consecutive weeks with $\mathrm{CO}$ or FOH and submitted to $\mathrm{PH}$. In both $\mathrm{CO}$ and $\mathrm{FOH}$ treatment, the number of animals analyzed varied from 8 to 9 in each euthanasia time-point. Data are means \pm SEM. Statistics by two-way ANOVA followed by Tukey test: a) statistically different from $\mathrm{CO}$ group in the same euthanasia time-point

In the present study apoptosis was evaluated by counting $\mathrm{AB}$ using fluorescence microscopy ${ }^{8}$. Advantages of this method are the fast identification of $\mathrm{AB}$ due to their strong fluorescence in $\mathrm{H} \& \mathrm{E}$-stained liver sections and increased sensitivity, since small fluorescent $\mathrm{AB}$, usually not recognized by transmitted light microscopy, can also be identified ${ }^{8}$. Figure 3 shows an example of a fluorescent hepatic $\mathrm{AB}$ stained with $\mathrm{H} \& \mathrm{E}$. Figure 4 shows $\mathrm{AI}$ of animals of $\mathrm{FOH}$ and $\mathrm{CO}$ groups. Compared to $\mathrm{CO}$ group, $\mathrm{FOH}$ group presented higher $(\mathrm{p}<0.05) \mathrm{AI} 0.5 \mathrm{~h}$ after $\mathrm{PH}$. No differences $(\mathrm{p}>0.05)$ were observed between $\mathrm{FOH}$ and $\mathrm{CO}$ groups in the other euthanasia time-points.

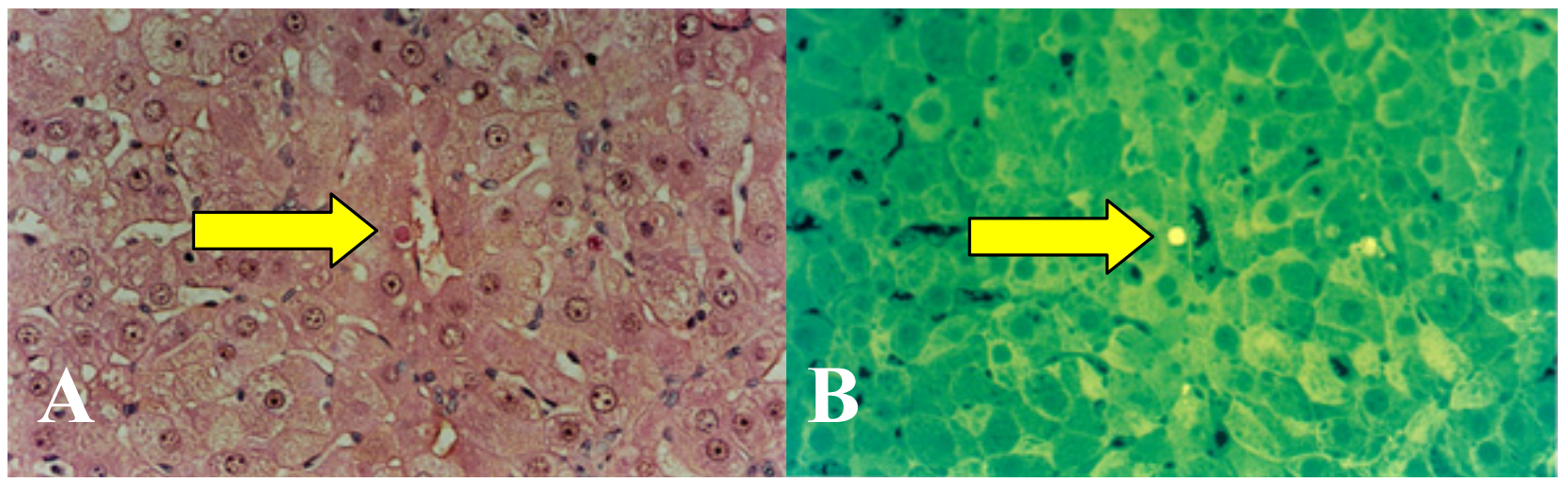

FIGURE 3 - Hepatic apoptotic body visualized by transmitted light microscopy (A) and fluorescent microcopy (B). 40X objective 


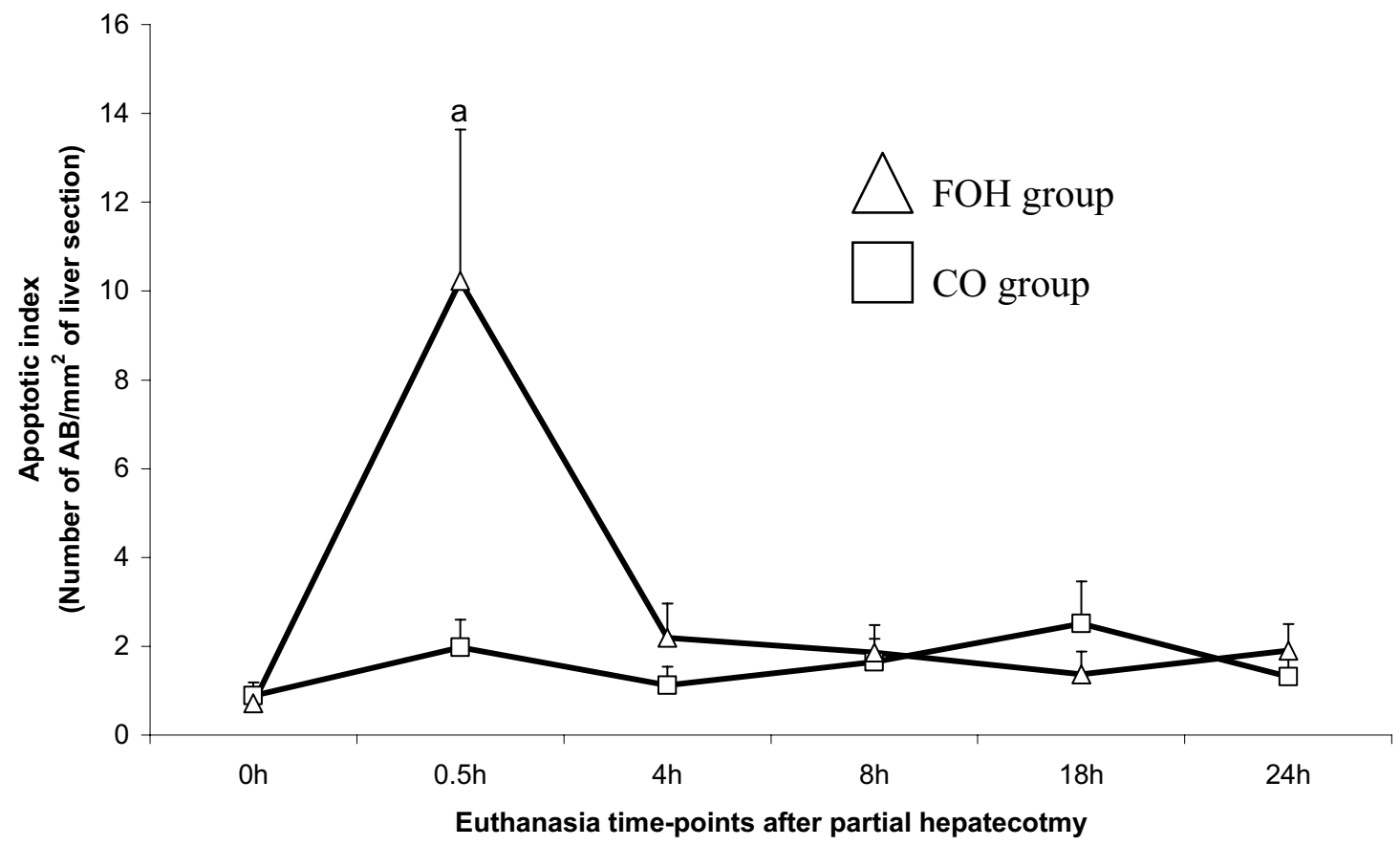

FIGURE 4 - Hepatic apoptosis index (AI) of rats treated with $\mathrm{CO}$ or FOH for 2 consecutive weeks and submitted to $\mathrm{PH}$. In both $\mathrm{CO}$ and $\mathrm{FOH}$ treatment, the number of animals analyzed varied from 8 to 9 in each euthanasia time-point. Data are means \pm SEM. Statistics by two-way ANOVA followed by Tukey test: a) statistically different from CO group in the same euthanasia time-point

\section{Discussion}

The effects of chemopreventive agents on cell proliferation and apoptosis can be investigated in detail using $70 \% \mathrm{PH}$, a classic and synchronous model of liver regeneration ${ }^{12}$. Since hepatic regeneration in rodents is similar to that observed in humans, the results obtained from rodents can be also applicable to the human liver ${ }^{18}$. The priming stage $\left(\mathrm{G}_{0} / \mathrm{G}_{1}\right.$ transition) comprises the first 4-6 h, followed by progression that lasts 12-16 h. Hepatic DNA synthesis (S phase) starts around $18 \mathrm{~h}$ and peaks at $24 \mathrm{~h}$ after surgery $^{12-14}$

Cell proliferation has been suggested to involve a regulated passage through some checkpoints which ensure the proper timing of cell cycle events ${ }^{19}$. Compounds that prevent cell cycle progression can be used as negative regulators of cell proliferation in proliferative diseases such as cancer $^{20}$. FOH induced $G_{0} / G_{1}$ arrest which leaded to apoptosis and inhibition of cell proliferation in lung and leukemia cells ${ }^{21,22}$. In the present study, rats treated with $\mathrm{FOH}$ presented a reduced number of PCNA positive nuclei 24 hours (S phase) after 70\% PH. In addition, $\mathrm{FOH}$ effect on cell proliferation was preceded by apoptosis induction started $0.5 \mathrm{~h}\left(\mathrm{G}_{0} / \mathrm{G}_{1}\right.$ transition) after surgical procedure.

Apoptosis is considered an ideal way of eliminating undesired or genetically altered cells without the induction of inflammatory response ${ }^{22}$. Arsenite ${ }^{23}$, manganese ${ }^{24}$ and 5-(N,Nhexamethylene)-amiloride ${ }^{25}$, when administered subcutaneously after $\mathrm{PH}$, induced apoptosis $4 \mathrm{~h}$ after surgery. Thus considering the present and previously data ${ }^{23-25}$ it seems that apoptosis occurs preferentially during the priming stage of liver regeneration. The differences regarding the time of apoptosis induction between these above mentioned studies and the present study could be related to the fact that FOH administration by gavage was started 2 weeks before the PH which could increase the hepatic concentration of this isoprenoid.

We suggest that similarly to in vitro studies, in the present study FOH induced a $\mathrm{G}_{0} / \mathrm{G}_{1}$ cell cycle arrest that leaded to apoptosis induction after $\mathrm{PH}$. This could be associated to the reduced number of PCNA positive cells at the $\mathrm{S}$ phase as also described for retinoic acid $^{14}$, quercetin ${ }^{26}$ and 5-(N,N-hexamethylene)-amiloride ${ }^{25}$. In those studies rats submitted to $\mathrm{PH}$ and treated with these substances presented inhibition of DNA synthesis that was also preceded by apoptosis induction starting during early $\mathrm{G}_{1}$ phase.

In summary, the results of the present study reinforce $\mathrm{FOH}$ as an attractive candidate for cancer prevention ${ }^{8,9}$ and therapy ${ }^{10}$. In order to provide further information regarding FOH actions on cell cycle phases, future studies could focus on the molecular pathways involved in both apoptosis and cell proliferation in vivo.

\section{Conclusion}

The farnesol induces apoptosis and decreases cell proliferation during liver regeneration after partial hepatectomy.

\section{References}

1. Jemal A, Siegel R, Ward E, Hao Y, Xu J, Murray T, Thum MJ. Cancer statistics, 2008. CA Cancer J Clin. 2008;58(2):71-96. 
2. Sporn MB, Suh N. Chemoprevention: an essential approach to controlling cancer. Nat Rev Cancer. 2002;2(7):537-43.

3. Wargovich MJ, Jimenez A, Mckee K, Steele VE, Velasco M, Woods J, Price R, Gray K, Kelloff GJ. 2000. Efficacy of potential chemopreventive agents on rat colon aberrant crypt formation and progression. Carcinogenesis. 2000;21(6):1149-55.

4. Rao CV, Newmark HL, Reddy BS. Chemopreventive effect of farnesol and lanosterol on colon carcinogenesis. Cancer Detect Prev. 2002;26(6):419-25.

5. Burke YD, Stark MJ, Roach SL, Sen SE, Crowell PL. Inhibition of pancreatic cancer grown by the dietary isoprenoids farnesol and geraniol. Lipids. 1997;32(2):151-6.

6. Burke YD, Ayoubi AS, Werner SR, McFarland BC, Heilman DK, Ruggeri BA, Crowell PL. Effects of the isoprenoids perillyl alcohol and farnesol on apoptosis biomarkers in pancreatic cancer chemoprevention. Anticancer Res. 2002;22(6A):3127-34.

7. Espindola RM, Mazzantini RP, Ong TP, de Conti A, Heidor R, Moreno FS. Geranylgeraniol and $\beta$-ionone inhibit hepatic preneoplastic lesions, cell proliferation, total plasma cholesterol and DNA damage during the initial phases of hepatocarcinogenesis, but only the former inhibits NF-KB activation. Carcinogenesis. 2005;26(6):1091-9.

8. Ong TP, Heidor R, de Conti A, Dagli ML, Moreno FS. Farnesol and geraniol chemopreventive activities during the initial phases of hepatocarcinogenesis involve similar actions on cell proliferation and DNA damage, but distinct actions on apoptosis, plasma cholesterol and HMGCoA reductase. Carcinogenesis. 2006;27(6):1194-203.

9. Horn TL, Long L, Cwik MJ, Morrissey RL, Kapetanovic IM, McCormick DL. Modulation of hepatic and renal drug metabolizing enzyme activities in rat by subchronic administration of farnesol. Chem Biol Interact. 2005;152(2-3)152:79-99.

10. Scheper MA, Shirtliff ME, Meiller TF, Peters BM, Jabra-Rizk MA. Farnesol, a fungal quorum-sensing molecule triggers apoptosis in human oral squamous carcinoma cells. Neoplasia. 2008;10(9):954-63.

11. Mo H, Elson CE. Studies of the isoprenoid-mediated inhibition of mevalonate synthesis applied to cancer chemotherapy and chemoprevention. Exp Biol Med. 2004;229(7):567-85.

12. Fausto N. Liver regeneration. J Hepatol. 2000;32(1 Suppl):19-31.

13. Tarlá MR, Ramalho FS, Ramalho LNZ, Castro e Silva T, Brandão, DF, Ferreira J, Castro e Silva O, Zucoloto, S. A molecular view of liver regeneration. Acta Cir Bras. 2006;21(Suppl 1):58-62.

14. Ozek A, Tsukamoto I. Retinoic acid repressed the expression of c-fos and c-jun and induced apoptisis in regeneration rat liver after partial hepatectomy. Biochem Biophys Acta. 1999;1450(3):308-19.
15. Higgins GM, Anderson RM. Experimental pathology of the liver. Restoration of the liver of the white rat following partial surgical removal. Arch Pathol. 1931;12:186-202.

16. Fonseca EMAV, Chagas CEA, Mazzantini RP, Heidor R, Ong TP, Moreno FS. All-trans and 9-cis retinoic acids, retinol and beta-carotene chemopreventive activities during the initial phases of hepatocarcinogenesis involve distinct actions on glutathione S-transferase positive preneoplastic lesions remodeling and DNA damage. Carcinogenesis. 2005;26(11):1940-6. 17. Goldsworth TL, Fransson-Steen R, Maronpot RR. Importance of and approaches to quantification of hepatocytes apoptosis. Toxicol Pathol. 1996;24(1):24-35.

18. Fausto N. Liver regeneration: from laboratory to clinic. Liver Transplant. 2001;7(10):835-44.

19. Hartwell LH, Weinert TA. Checkpoints: controls that ensure the order of cell cycle events. Science. 1989;246(4930):629-34.

20. Chen HW, Huang HC. Effect of curcumin on cell cycle progression and apoptosis in vascular smooth muscle cells. Br J Pharmacol. 1998;124(6):1029-40.

21. Wright MM, McMaster CR. Phospholipid synthesis, diacylglycerol compartmentation, and apoptosis. Biol Res. 2002;35(2):223-9.

22. Lo Muzio L, Pannone G, Staibano S, Mignogna MD, Rubini C, Mariggio MA, Procaccini M, Ferrari F, De Rosa G, Altieri DC. Survivin expression in oral squamous cell carcinoma. Br J Cancer. 2003;89(12):2244-8.

23. Suzuki T, Tsukamoto I. Arsenite induced apoptosis in hepatocytes through an enhancement of the activation of Jun N-terminal kinase and p38 mitogen-activated protein kinase caused by partial hepatectomy. Toxicol Lett. 2006;165(3):257-64.

24. Suzuki T, Tsukamoto I. Manganese-induced apoptosis in hepatocytes after hepatectomy. Eur J Pharmacol. 2005;525(1-3):48-53.

25. Suzuki T, Tsukamoto I. Apoptosis induced by 5 -(N,N-hexamethyllene)amilorida in regeneration liver after partial hepatectomy. Eur J Pharmacol. 2004;503(1-3):1-7.

26. Iwao K, Tsukamoto I. Quercetin inhibited DNA synthesis and induced apoptosis associated with increase in c-fos mRNA leval and the upregulation of p21WAK1CIP1 mRNA and protein expression during liver regeneration after partial hepatectomy. Biochim Biophys Acta. 1999;1427(1):112-20.

\section{Acknowledgement}

The authors would like to thanks Miss Silvania M.P. Neves for providing the care and maintenance of the animals.

\section{Correspondence:}

Conflict of interest: none

Prof. Fernando Salvador Moreno

Laboratory of Diet, Nutrition and Cancer

Av. Prof. Lineu Prestes, 580/Bloco 14

05508-900 Sao Paulo - SP Brazil

Phone: (55 11)3091-1492

Fax: (55 11)3815-4410

rmoreno@usp.br

Received: March 18, 2009

Review: May 12, 2009

Accepted: June 16, 2009

\section{How to cite this article}

Chagas CEA, Vieira A, Ong TP, Moreno FS. Farnesol inhibits cell proliferation and induces apoptosis after partial hepatectomy in rats. Acta Cir Bras. [serial on the Internet] 2009 Sept-Oct;24(5). Available from URL: http://www.scielo.br/acb 